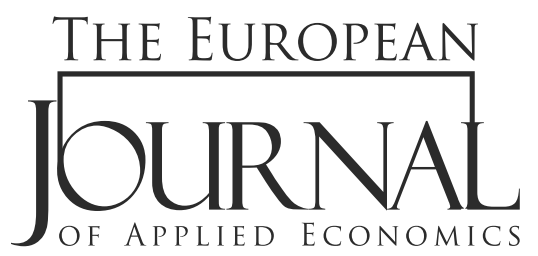

\title{
OWNERSHIP CONCENTRATION AND FIRM PERFORMANCE: AN EMPIRICAL ANALYSIS IN OMAN
}

\author{
Mawih Kareem Al Ani*, Asma Mohammed Al Kathiri
}

Assistant Dean, Associate Professor of Accounting College of Commerce and Business Administration Dhofar University, Oman

\begin{abstract}
:
This study investigates the effect of ownership concentrations on firm performance. A sample of 115 Omani companies in three sectors (i.e. financial, industrial and service) was selected for the study. The sample companies selected were listed in the Muscat Securities Market for a period of five years (2011-2015). Four types of ownership were analysed, namely, the ownership of Omani investors, the Gulf Cooperation Council (GCC) country investors, Arab non-GCC investors, and foreign investors. Firm performance was measured by return on assets (ROA), return on equity (ROE), and market fair value (MFV) of share. Panel regression was used to study the effect of ownership concentrations on firm performance. Results reveal a positive and significant effect of GCC countries and foreign investors on ROA only in the industrial sector. Moreover, a positive and significant effect of Omani and GCC countries investors was found on MFV in the service sector. Finally, results found no effect of ownership concentrations on ROE in all sectors.
\end{abstract}

\section{Article info:}

Received: January 19, 2019

Correction: February 19, 2019

Accepted: June 08, 2019

\section{Keywords:}

ownership structure, return on assets, return on equity, market fair value, Oman 


\section{INTRODUCTION}

Every capital market has its approach to building ownership of its listed companies. The vision of the capital market controls the type of ownership structure that a company decides to adopt. "The ownership structure is defined by the distribution of equity with regard to votes and capital, as well as the identity of the equity owners" (Owiredu, Oppong \& Churchull, 2014). Ownership concentration refers to the percentage of shares held by an owner relative to the total shareholding of the firm. It is contrary to ownership identity, which refers to the actual names of major shareholders (Owiredu et al., 2014).

Ownership concentrations are one of the frequently debated issues in the published studies. The effect of different types of shareholders on firm performance was also studied. Moreover, many types of ownership concentrations underwent individual and collective research. Ownership concentrations, such as a large shareholder, and foreign, institutional, family, block-holder, managerial, employee, government, retail, and domestic ownerships were studied in the earlier literature. Previous studies have examined the effect of ownership concentration on firm performance. However, conclusive evidence to demonstrate the effect of ownership concentration on firm performance remains lacking (Rajput \& Bharti, 2015).

In Oman, a different structure of the ownership of companies exists as listed in the Muscat Securities Market (MSM). This structure is defined on the basis of one general criterion, namely, ownership identity of the investor, regardless of nationality (i.e. Omani or non-Omani). The term "Omani investor" refers to all Omani individuals or institutions that can buy or sell shares in MSM. However, non-Omani investors are grouped into three clusters, namely: 1) investors from the Gulf Cooperation Council (GCC) countries, which have nearly similar characteristics to Omani investors; 2) Arab investors who are excluded from GCC countries, and 3) foreign investors. According to the foreign capital investment law in Oman No. 102, 1994 (and its amendments), a foreign investor is defined as a legal or natural person who owns a percentage of shares of companies inside Oman. GCC investors are individual investors or institutions that operate in other GCC countries outside Oman, whereas Arab non-GCC investors are individual investors or institutions that operate in Arab non-GCC countries. In summary, four types or identities of shareholders in Omani companies are listed in MSM, namely, Omani, GCC, Arab non-GCC and foreign investors.

As observed, the ownership or shareholding structure of Omani-listed companies in MSM is nonuniform. In several companies, the Omani investor has a high percentage of shares that can reach up to $99 \%$. In other companies, it is the foreign investor who has a high percentage of shares. Moreover, a different ownership or shareholding structure exists across the three sectors in MSM. Thus, predicting the style of this structure is extremely difficult. For example, in the industrial sector, GCC investors have a high level of ownership in certain companies, but the opposite is true in the service sector. Therefore, the following question is raised: Will the differences in ownership percentage of each shareholder possibly affect the financial and market performance of the listed companies?

This study aims to investigate the effect of ownership percentage of each shareholder's type or identity on the firm performance of Omani companies listed in the MSM for a period of five years (2011-2015). The ownership percentage of each concentration is the independent variable, which has four sub-independent variables, namely, ownership percentage of Omani investors, ownership percentage of GCC investors, ownership percentage of Arab non-GCC investors, and ownership percentage of foreign investors. Conversely, out of the three dependent variables, two are proxies of financial performance, namely, return on asset (ROA) and return on equity (ROE). The third variable is market performance, which is measured by the market fair value (MFV) of the share at the closing price. 
The current area of research remains scarce, as only a few researchers have focused on this problem. In 2016, Al-Matari and Al-Arussi studied a sample of 81 companies from only the industrial and service sectors for a period of three years (2012-2014). They focused only on financial performance in terms of profitability. A research gap has arisen owing to the lack of empirical study concerning this problem. The current study aims to fill this research gap, and be among the pioneer studies that investigate the effect of ownership concentration on firm performance in the Omani context. Moreover, the present study covers all companies listed in three sectors, namely, industry, services and finance, in MSM.

The remainder of the paper is structured as follows: Section Two provides a literature review, Section Three discusses the research method and models, Section Four presents the findings for each model, while Section Five concludes.

\section{LITERATURE REVIEW}

A significant amount of empirical evidence exists on the impact and association of ownership concentration and firm performance. One of the most important findings from the previous literature is that ownership structure has had important implications for corporate governance, protection of minority shareholders' interest, and other variables (Kuznetsov, Kapelyushnikov \& Dyomina, 2010). Empirical evidence from prior studies was derived from different types of ownership concentration and various measures of firm performance. Earlier researchers studied one or more ownership concentrations, and the majority used ROE, ROA, and Tobin's Q as dependent variables. In other words, they investigated the effect of ownership concentration on financial performance and firm value. Conversely, a few studies looked into the effects of ownership concentration on stock market performance. However, the results are mixed. Most studies concluded with a positive effect, whereas the opposite is true for other studies. Several researchers obtained mixed or no results. Therefore, the past literature can be classified into four clusters.

\section{Literature Review-Positive Effect}

In this cluster, previous studies observed a positive effect of ownership concentrations on firm performance. (e.g. Srithanpong, 2012; Alimehmeti \& Paletta, 2012; Isik \& Soykan, 2013; Fauzi \& Locke, 2012; Rajput \& Bharti, 2015; Amran \& Ahmed, 2013; Yasser \& Al Mamun, 2017). These studies examined the effect of many types of ownership concentrations on financial performance, firm value, and market-based performance. For example, Srithanpong (2012) studied the effect of foreign ownership on performance. Rajput and Bharti (2015) investigated four types of ownership concentration models, namely, foreign institution, family, government, and retail ownerships. Alimehmeti and Paletta (2012) and Isik and Soykan (2013) researched the impact of only one model, namely, large shareholders, whereas Amran and Ahmed (2013) evaluated the impact of two models, namely, managerial and family ownerships. Fauzi and Locke (2012) assessed the effect of ownership structure on firm performance in 79 listed companies in New Zealand. Results of these studies showed a significant positive impact of all types of ownership concentrations on financial performance in terms of ROA and ROE, and firm value in terms of Tobin's $Q$ and market-based performance. The positive results confirm that the ownership concentrations being analysed in these studies might be less dispersed and more concentrated, which consequently increase financial performance, firm value, and market-based 
performance. For example, Alimehmeti and Paletta (2012: 45) showed a positive association between ownership concentration and firm value. This result is 'confirming the agency perspective that higher concentration increases shareholder power and control aligning managers, shareholders' interests, and consequently increasing firm value.'

\section{Literature Review-Negative Effect}

Another cluster of research provides evidence of the negative effect of ownership concentrations on firm performance. Kuznetsov et al. (2010), Al-Saidi and Al-Shammari (2014), Wang and Shailer (2015) and Shahab-u-Din and Javid (2011) are examples of such studies.

The negative impact has many explanations. One is that concentrated ownership might largely influence firm performance. For example, Al-Saidi and Al-Shammari (2014) pointed out that large shareholders significantly influence managers, who act only in the interest of large shareholders. In other words, extra attention is given to these shareholders, whereas less attention is given to other ownership types. Din and Javid (2011) provided another explanation for this negative relation. Their research was related to the control of the concentrated ownership of the company in which the said ownership will make decisions that serve their interests but influence other ownership concentrations.

\section{Literature Review-Mixed Results}

Many empirical studies concluded, with mixed results the association between ownership concentrations and firm performance. Results showed positive, negative, or no effects. Srivastava (2011), Chen (2012), Khan and Nouman (2017), Ahmed and Abdel Hadi (2017), Ongore (2011), Pathirawasam and Wickremasinghe (2012), Vintilă, Gherghina, and Nedelescu (2014) Khamis, Hamdan, and Elali (2015) and Zakaria, Purhanudin, and Palanimally (2014) are examples of these types of evidence.

Results of the previous literature are dependent on the power held by the type of ownership concentration. For example, Ahmed and Abdel Hadi (2017) found that the government ownership concentration positively affects performance, because the government is fully authorised to enact laws and regulations. Furthermore, it significantly supports the business environment. Moreover, a negative association is observed between ROE and insider ownership, because this class of ownership concentration can damage the profitability of the firm instead of improving it. Khan and Nouman (2017) found a negative relationship between managerial ownership and performance, because managers favour family relations over performance, which is damaging for the organisation. In the same study, the relationship between block-holder ownership concentration and performance was significantly positive because this class of ownership positively reduces agency problems. 


\section{Literature Review-No Association}

The final group of evidence pertains to empirical studies that found no relationships or impacts of ownership concentrations on firm performance. Few studies, such as Qin, Mishra and Smyth (2012) and Abdul Rahman and Md Reja (2015), concluded this result for certain reasons. For example, Abdul Rahman and Md Reja (2015) concluded that the model used in several studies does not explain the changes in firm performance owing to other factors, such as research sample, variables, period of study, or statistical data.

Accordingly, ownership concentration is a multidimensional concept that can be measured using various measures, such as managerial, foreign, family, and large ownerships. In Oman, ownership concentration exerts a relatively substantial role. Furthermore, knowledge of the leaders in the listed companies and how they influence firm performance is very important. Most of these measures are covered by the abovementioned review of the existing literature. However, the ownership concentrations (Omani and non-Omani investors) employed by MSM in Oman have not undergone optimal analyses. This observation creates a gap requiring analysis. Moreover, no consensus exists on the empirical evidence of ownership concentration and firm performance. The available results are mixed, which require further research of the concept. The present study intends to fill this research gap.

In alignment with most of the literature reviews, we present the hypotheses of the study.

H1: Ownership concentration of Omani listed firms has a positive effect on ROA.

$\mathbf{H}_{2}$ : Ownership concentration of Omani listed firms has a positive effect on ROE.

$\mathbf{H}_{3}$ : Ownership concentration of Omani listed firms has a positive effect on MFV.

\section{METHODOLOGY}

\section{Population, Sample and Data}

The population for this study consists of 118 companies listed in the industrial, financial, and service sectors of the MSM during 2011-2015. This population is divided into three sectors, namely, financial (35), industrial (45), and services (38) sectors. The sample of the study covered (115) companies with a total of 575 final observations. The study excluded three listed companies from the service sector, because of unavailable data for all variables within the study period. The firm-level panel data for the study were primarily obtained from the MSM database for 2011-2015. All data are available in the link (Ani, Mawih Kareem, 2019; 'ownership concentration in Oman', Mendeley Data, https://data.mendeley. $\mathrm{com} /$ datasets/6gmd $83 \mathrm{wznm} / 3$. The following table shows the size of the population and the sample:

Table 1 Population and Sample

\begin{tabular}{ccccc}
\hline Sector & Service sector & Industrial sector & Financial sector & Total \\
\hline Size of population & 38 & 45 & 35 & 118 \\
\hline Sample size & 35 & 45 & 35 & 115 \\
\hline $\begin{array}{c}\text { Sample/population } \\
\text { ratio }\end{array}$ & $92.1 \%$ & $100 \%$ & $00 \%$ & $97.45 \%$ \\
\hline Companies excluded & 3 & 0 & 0 & $2.55 \%$ \\
\hline
\end{tabular}




\section{Variables}

This study aims to empirically investigate the effect of ownership concentrations on firm performance of Omani companies listed in MSM during 2011-2015. The independent variables are the percentage of ownership concentrations:

-Percentage of Omani Ownership Concentration (OOC)

-Percentage of Arab Gulf Ownership Concentration (GCCOC)

-Percentage of Arab non-GCC Ownership Concentration (ANGCCOC)

-Percentage of Foreign Ownership Concentration (FOC)

The dependent variables are as follows: financial performance, which is measured by ROA and ROE; and market-based performance, which is measured by MFV of share on the closing date at the end of the year.

The study employed three general measures of dependent variables to avoid any problems that belong to the firm or sector. In addition, the study used three general measure variables, which have also been utilised in most studies. A commonly used measure of firm performance is ROA, which provides a picture of the effectivity of firm management in terms of generating profit using available assets. Another good measure of firm performance is ROE, which is a measure of the effectivity of shareholders' funds being used by the management of the firm. ROA and ROE have been employed as measures for financial performance in several studies (Unsal, Ugurlu \& Sakinc, 2009; Srivastava, 2011; Rajput and Bharti, 2015). Apart from ROA and ROE, researchers have also used another measure, namely, MFV, for market-based performance (e.g. Kumar, 2004; Srivastava, 2011). This measure reflects the movement of share price, which can be easily understood by investors. Table 2 provides the definition of variables.

Table 2 Definition of Variables

\begin{tabular}{ll}
\hline Variable & Definition \\
\hline MFV & Closing price at the end of the year \\
\hline ROA & Net income after tax $\div$ total assets \\
\hline ROE & Net income after tax $\div$ total equity \\
\hline Percentage of ownership & Number of shares owned by the total shares of the company \\
\hline
\end{tabular}

The study used ROA to measure the firm's ability to generate profit from the total assets and ROE to reflect the returns of shareholder equity. ROA and ROE were calculated in accordance with the abovementioned formula in Table 2. The means of ROA, ROE, and MFV were calculated for each firm, ownership concentration, sector and year. Lastly, data distributions within each sector and year were assessed. 


\section{Model Specification}

In this study, panel regression was used to recognise the impact of independent and dependent variables. Afterwards, an equation was formulated to evaluate the influence of independent variables on dependent variables. Data were organised in the form of a balanced panel. The panel data models (multiple regression analysis) were used for data analysis using IBM Statistical Package for the Social Sciences (SPSS 22). The general form of the models used was

$$
\text { FPit }=\alpha+\beta 100 C i t+\beta 2 \text { GCCOCit }+\beta 3 \text { ANGCCOCit }+\beta 4 \text { FOCit }+ \text { eit }
$$

where

$F P=$ firm performance

$A=$ constant term

$\beta=$ parameters are coefficients for estimation

$e=$ error

$i=$ firm

$t=$ time.

Three univariate regression models were drawn from the cited general form to study the impact of ownership concentrations on firm performance as follows:

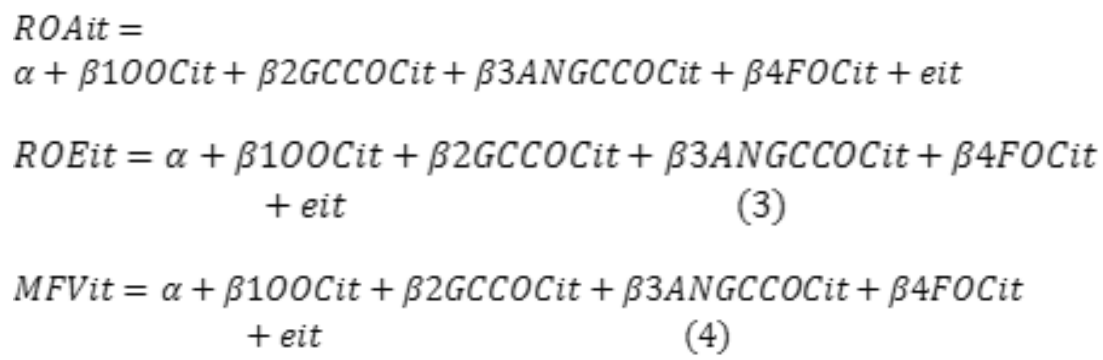

The three univariate regression models were applied in the three sectors in MSM, namely, the finance, industrial, and service sectors. 


\section{RESULTS AND DISCUSSION}

\section{Descriptive Statistics}

Table 3 shows the descriptive statistics for all variables.

Table 3 Descriptive Statistics

\begin{tabular}{cccccc}
\hline \multirow{2}{*}{ Variables } & $\mathrm{N}$ & Minimum & Maximum & Mean & Std. Deviation \\
\cline { 2 - 6 } & Statistic & Statistic & Statistic & Statistic & Statistic \\
\hline OOC & 115 & 0.01 & 1.00 & 0.7782 & 0.24751 \\
\hline GCCOC & 115 & 0.00 & 0.99 & 0.1421 & 0.21830 \\
\hline ANGCCOC & 115 & 0.00 & 0.65 & 0.0125 & 0.14573 \\
\hline FOC & 115 & 0.00 & 0.17 & 0.070 & 0.01927 \\
\hline ROE & 115 & -1.39 & 1.74 & 0.1021 & 0.51014 \\
\hline ROA & 115 & -0.02 & 1.52 & 0.1357 & 0.21231 \\
\hline MFV & 115 & 0.00 & 4.74 & 0.8512 & 1.08973 \\
\hline
\end{tabular}

Table 3 shows that Omani investors have the majority of ownership in the sample at approximately $78 \%$, followed by Arab investors from GCC countries at 14\%, and foreign investors at approximately $7 \%$. Arab investors from non-GCC countries own the least ownership at approximately $1 \%$. The mean of $\mathrm{ROE}$ is $10 \%$. However, this finding does not imply that the listed firms can increase the wealth of investors because the minimum of ROE is negative. In other words, several companies are unable to generate profit for their shareholders. The mean of ROA is $13.5 \%$, which does not imply that the listed firms can generate profit from their assets. The minimum of ROA is negative, which indicates that certain companies are unable to generate profit from their assets. Finally, the mean of MFV is positive, which denotes that investors have a positive perspective about the listed firm in terms of market performance.

\section{Correlation matrix and Multicollinearity}

The study has four independent variables of ownership concentration, namely, OOC, GCCOC, ANGCCOC, and FOC. The three dependent variables are ROA, ROE and MFV. Table 4 summarises the results of correlation and multicollinearity:

Table 4 Correlation Matrix and Multicollinearity

\begin{tabular}{|c|c|c|c|c|c|c|c|c|}
\hline Sector & Variables & OOC & GCCOC & ANGCCOC & FOC & $\mathrm{ROA}$ & ROE & MFV \\
\hline \multirow{7}{*}{ 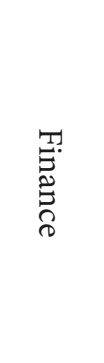 } & OOC & 1 & & & & & & \\
\hline & GCCOC & 0.203 & 1 & & & & & \\
\hline & ANGCCOC & -0.112 & 0.356 & 1 & & & & \\
\hline & FOC & 0.040 & 0.124 & 0.237 & 1 & & & \\
\hline & $\mathrm{ROA}$ & -0.214 & $0.427^{\star}$ & 0.018 & -0.251 & 1 & & \\
\hline & $\mathrm{ROE}$ & -0.028 & 0.059 & 0.077 & -0.166 & 0.378 & 1 & \\
\hline & MFV & -0.246 & 0.232 & -0.056 & -0.076 & $0.414^{*}$ & 0.147 & 1 \\
\hline
\end{tabular}




\begin{tabular}{|c|c|c|c|c|c|c|c|c|}
\hline \multirow{7}{*}{ 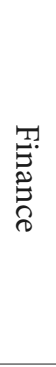 } & OOC & 1 & & & & & & \\
\hline & GCCOC & -0.044 & 1 & & & & & \\
\hline & ANGCCOC & 0.159 & $0.441^{*}$ & 1 & & & & \\
\hline & FOC & 0.222 & 0.212 & -0.246 & 1 & & & \\
\hline & ROA & -0.201 & -0.025 & -0.021 & $0.411^{\star *}$ & 1 & & \\
\hline & ROE & -0.082 & 0.132 & 0.052 & -0.080 & 0.215 & 1 & \\
\hline & MFV & -0.186 & 0.148 & -0.013 & 0.106 & $0.358^{\star}$ & $0.421^{\star}$ & 1 \\
\hline \multirow{7}{*}{ 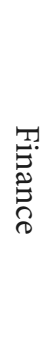 } & OOC & 1 & & & & & & \\
\hline & GCCOC & -0.036 & 1 & & & & & \\
\hline & ANGCCOC & 0.115 & -0.156 & 1 & & & & \\
\hline & FOC & $0.351^{*}$ & 0.241 & 0.103 & 1 & & & \\
\hline & ROA & -0.082 & 0.110 & -0.028 & -0.039 & 1 & & \\
\hline & ROE & -0.100 & 0.193 & 0.229 & -0.143 & .256 & 1 & \\
\hline & MFV & $0.365^{\star}$ & $0.422^{*}$ & -0.367 & 0.340 & 0.125 & 0.016 & 1 \\
\hline
\end{tabular}

Table 4 indicates that multicollinearity is not a problem as the correlations within all independent and dependent variables are relatively low, whereas the majority of the variables are non-significant. The remainder is significant, but less than 0.80 . Therefore, we infer that all models are dependable.

Table 4 shows a number of significant associations among dependent (ROA, ROE and MFV) and independent (OOC, GCCOC, ANGCCOC and FOC) variables. For example, ROA has a significant positive association with GCCOC (0.447) at 0.05 in the finance sector, whereas ROE and MFV have no relationship with all ownership concentration indicators (independent variables). In the industrial sector, ROA is also positively correlated with FOC $(0.411)$ at 0.01 , whereas ROE and MFV have no relationships with all independent variables. In the service sector, MFV has a positive relationship with OOC and GCCOC at 0.05 . However, a weak and statistically non-significant correlation is observed among ROA, ROE and MFV and all independent variables. 


\section{Findings of Model 1 (ROA)}

Table 5 shows the regression results of model 1. The table provides a snapshot of the regression results on an aggregate basis. In this model, the dependent variable is ROA.

Table 5 Regression Results of Model 1 (ROA)

\begin{tabular}{|c|c|c|c|c|c|c|c|c|c|c|}
\hline \multirow{3}{*}{ Model } & \multirow[b]{2}{*}{$\operatorname{I} . V(s)^{*}$} & \multicolumn{3}{|c|}{ Finance Sector } & \multicolumn{3}{|c|}{ Industrial Sector } & \multicolumn{3}{|c|}{ Service Sector } \\
\hline & & $\begin{array}{l}\text { Coeffi- } \\
\text { cients }\end{array}$ & T-Value & Sig & $\begin{array}{c}\text { Coeffi- } \\
\text { cients }\end{array}$ & T-Value & Sig. & $\begin{array}{c}\text { Coeffi- } \\
\text { cients }\end{array}$ & T-Value & Sig \\
\hline & Constant & 2.568 & 4.688 & 0.000 & 1.154 & 2.354 & .023 & 0.093 & 6.064 & 0.000 \\
\hline \multirow{4}{*}{ ROA } & OOC & -0.112 & -0.306 & 0.762 & -0.031 & -0.486 & 0.629 & -0.133 & -1.249 & 0.222 \\
\hline & GCCOC & 0.486 & 2.056 & 0.049 & 0.086 & 0.195 & 0.847 & 0.102 & 0.551 & 0.586 \\
\hline & ANGCCOC & -0.109 & -0.371 & 0.713 & 0.103 & 0.142 & 0.887 & -0.107 & -0.151 & 0.881 \\
\hline & FOC & -0.148 & -1.290 & 0.207 & 1.414 & 2.995 & 0.004 & 0.061 & -0.092 & 0.928 \\
\hline \multicolumn{2}{|c|}{ R-Squared } & \multicolumn{3}{|c|}{0.103} & \multicolumn{3}{|c|}{0.170} & \multicolumn{3}{|c|}{0.013} \\
\hline \multicolumn{2}{|c|}{ F-Value } & \multicolumn{3}{|c|}{2.184} & \multicolumn{3}{|c|}{3.008} & \multicolumn{3}{|c|}{0.125} \\
\hline \multicolumn{2}{|r|}{ Sig. } & \multicolumn{3}{|c|}{0.012} & \multicolumn{3}{|c|}{0.040} & \multicolumn{3}{|c|}{0.945} \\
\hline
\end{tabular}

*I.V(s): Independent variables

Table 5 shows that GCCOC has a significant positive impact on ROA in the finance sector at 0.05 . OCC, ANGCCOC, and FOC have a non-significant relationship with ROA. In the industrial sector, FOC has a significant positive impact on ROA at 0.05. OCC, GCCOC, and ANGCCOC have a nonsignificant relationship with ROA. In the service sector, no significant impact is observed among all types of ownership concentrations and ROA.

\section{Findings of Model 2 (ROE)}

Table 6 shows the regression results of model 2. In this model, the dependent variable is ROE.

Table 6 Regression Results of Model 2 (ROE)

\begin{tabular}{|c|c|c|c|c|c|c|c|c|c|c|}
\hline \multirow{3}{*}{ Model } & \multirow[b]{2}{*}{ I.V $(s)$} & \multicolumn{3}{|c|}{ Finance Sector } & \multicolumn{3}{|c|}{ Industrial Sector } & \multicolumn{3}{|c|}{ Service Sector } \\
\hline & & $\begin{array}{l}\text { Coeffi- } \\
\text { cients }\end{array}$ & T-Value & Sig & $\begin{array}{l}\text { Coeffi- } \\
\text { cients }\end{array}$ & T-Value & Sig. & $\begin{array}{l}\text { Coeffi- } \\
\text { cients }\end{array}$ & T-Value & Sig \\
\hline & Constant & 1.153 & 2.564 & 0.016 & 0.085 & 0.884 & 0.381 & 0.093 & 4.039 & 0.000 \\
\hline \multirow{4}{*}{ ROE } & OOC & 0.012 & 0.694 & 0.493 & -0.001 & -0.642 & 0.524 & 0.101 & 0.743 & 0.464 \\
\hline & GCCOC & 0.051 & 0.537 & 0.595 & 0.091 & 0.794 & 0.431 & 0.121 & 0.961 & 0.345 \\
\hline & ANGCCOC & -0.017 & -0.020 & 0.984 & 0.001 & 0.209 & 0.836 & 0.153 & 1.242 & 0.224 \\
\hline & FOC & -0.017 & -0.020 & 0.984 & 0.001 & 0.209 & 0.836 & 0.153 & 1.242 & 0.224 \\
\hline \multicolumn{2}{|c|}{ R-Square } & \multicolumn{3}{|c|}{0.096} & \multicolumn{3}{|c|}{0.044} & \multicolumn{3}{|c|}{0.001} \\
\hline \multicolumn{2}{|c|}{ F-value } & \multicolumn{3}{|c|}{0.099} & \multicolumn{3}{|c|}{0.334} & \multicolumn{3}{|c|}{1.011} \\
\hline \multicolumn{2}{|r|}{ Sig. } & \multicolumn{3}{|c|}{0.960} & \multicolumn{3}{|c|}{0.801} & \multicolumn{3}{|c|}{0.403} \\
\hline
\end{tabular}


Table 6 reveals no significant impact on all types of ownership concentrations and ROE because the Sig. value of all variables is non-significant at 0.05 and 0.01 .

\section{Findings of Model 3 (MFV)}

Table 7 shows the regression results of model 3 with MFV as the dependent variable.

Table 7 Regression Results of Model 3 (MFV)

\begin{tabular}{|c|c|c|c|c|c|c|c|c|c|c|}
\hline \multirow{3}{*}{ Model } & \multirow[b]{2}{*}{ I.V(s) } & \multicolumn{3}{|c|}{ Finance Sector } & \multicolumn{3}{|c|}{ Industrial Sector } & \multicolumn{3}{|c|}{ Service Sector } \\
\hline & & $\begin{array}{c}\text { Coeffi- } \\
\text { cients }\end{array}$ & T-Value & Sig & $\begin{array}{c}\text { Coeffi- } \\
\text { cients }\end{array}$ & T-Value & Sig. & $\begin{array}{c}\text { Coeffi- } \\
\text { cients }\end{array}$ & T-Value & Sig \\
\hline & Constant & 1.552 & 2.083 & 0.047 & 1.635 & 3.436 & 0.001 & 1.489 & 1.899 & 0.068 \\
\hline \multirow{4}{*}{ MFV } & OOC & -0.106 & -0.807 & 0.427 & -0.256 & -1.282 & 0.207 & 0.486 & 0.627 & 0.038 \\
\hline & GCCOC & 0.112 & 0.823 & 0.417 & 0.211 & 1.116 & 0.271 & 1.210 & 2.461 & 0.020 \\
\hline & $\begin{array}{c}\text { A N G C - } \\
\text { COC }\end{array}$ & -0.085 & -0.541 & 0.593 & -0.003 & -0.128 & 0.899 & -0.115 & -0.988 & 0.332 \\
\hline & FOC & -0.006 & -0.456 & 0.652 & 0.114 & 0.841 & 0.405 & 0.017 & 0.134 & 0.895 \\
\hline \multicolumn{2}{|c|}{ R-Square } & & \multicolumn{2}{|c|}{0.059} & \multicolumn{3}{|c|}{0.027} & \multicolumn{3}{|c|}{0.122} \\
\hline \multicolumn{2}{|c|}{ F-value } & & \multicolumn{2}{|c|}{0.425} & \multicolumn{3}{|c|}{0.586} & \multicolumn{3}{|c|}{2.436} \\
\hline \multicolumn{2}{|r|}{ Sig. } & & \multicolumn{2}{|c|}{0.736} & \multicolumn{3}{|c|}{0.627} & \multicolumn{3}{|c|}{0.036} \\
\hline
\end{tabular}

In the service sector, OOC and GCCOC have a significant positive impact on MFV at 0.05 . FOC and ANGCCOC have a non-significant relationship with MFV. In the financial and industrial sectors, all types of ownership concentrations have no impact on MFV.

\section{Result Discussion}

\section{Model 1 (Dependent Variable-ROA)}

In the finance sector, results of this model imply that a high concentration of ownership for only GCC investors increases financial performance in terms of ROA, whereas that of other investors has no influence. R2 is only $10.3 \%$, which implies that independent variables included in the regression equation explain only $10.3 \%$ of changes in ROA, which is extremely low. The underlying reason for this result is because only one independent variable (GCCOC) is considered in the regression equation of this model. In the finance sector, most of the shareholders are from GCC countries, and their experience is reflected in achieving the profitability in this sector. This result is consistent with those of previous studies (e.g. Ahmed \& Abdel Hadi, 2017; Isik \& Soykan, 2013; Fauzi \& Locke, 2012; Rajput \& Bharti, 2015). These studies suggested a positive impact of ownership concentration on ROA.

In the industrial sector, FOC has a significant positive impact on ROA at 0.05. OCC, GCCOC and ANGCCOC have a non-significant relationship with ROA. These results imply that high concentrations of ownership for foreign investors increase financial performance in terms of ROA, whereas other concentrations of ownership have no influence on ROA. R2 is only $17.0 \%$, which implies that inde- 
pendent variables included in the regression equation explain only $17.0 \%$ of changes in ROA, which is extremely low. The possible explanation is that three of the independent variables are non-significant in this model and sector. According to these results, $\mathrm{H} 1$ is supported in the two sectors that confirm the positive impact of ownership concentration on ROA. In the industrial sector, foreign investors are the main investors because they bring technology, experience, skills and prestige together with capital to countries in which they invest. In addition, foreign investors plan to increase profit and avoid losses in this type of industry. This finding is consistent with that of Srithanpong (2014). That is, foreign ownership can improve firm performance. This result contradicts that of Khan and Nouman (2017), who suggested that foreign investors did not enhance firm performance.

No significant impact is found among all the types of ownership concentrations and ROA in the service sector,. This result indicates that an increase or decrease in ownership concentrations has no effect on ROA. Thus, $\mathrm{H} 1$ is not supported in this sector. This result is consistent with that of Khamis et al. (2015), who suggested that many ownership concentrations had no impact on firm performance, owing to the power of the investor and its role in the market.

\section{Model 2 (Dependent Variable-ROE)}

This result indicates that an increase or decrease in ownership concentrations for all sectors has no effect on ROE. In this model, H2 is not supported. Suggestively, ownership concentrations have no impact on ROE. Two potential reasons underlie this result. Firstly, investors in MSM are unable to monitor managers, and prevent the tendencies to accumulate wealth for their benefit. Secondly, despite the importance of ROE in assessing the performance of a company, investors in MSM seem to use their experience or other measures instead of ROE to distinguish between companies that are profit creators and profit burners.

The result of this model is inconsistent with those of previous studies, such as Srivastava (2011), Abbas, Naqvi and Mirza (2013) and Rajput and Bharti (2015). This inconsistency in results might be partially because an individual investor in Oman has less ability to maximise ROE compared with ROA. Institutional investors are prevalent in Oman and concerned with ROA as it appears in the MSM report (MSM companies Guide, 2017). However, this notion is consistent with that of Abdul Rahman and Md Reja (2015), who assumed that if investors have insufficient ownership percentage then it will not affect performance.

\section{Model 3 (Dependent Variable-MFV)}

The results of this model imply that a high concentration of ownership for Omani and GCC investors increases market performance in terms of MFV, whereas other concentrations of ownership have no influence on MFV. The value of R2 is 0.122 , which indicates that a $12.2 \%$ change in the independent variable is due to the dependent variable. This variation is not much, but is significant. The reason behind this result is that the three variables within the model did not yield any significant results., An increase or decrease in ownership concentrations has no effect on MFV in the finance and industrial sectors. In other words, no significant impact of any of the types of ownership concentrations and MFV was observed. Based on the cited results, $\mathrm{H} 1$ is supported in the service sector. 
However, we cannot confirm the same result in the two other sectors. Moreover, this result is consistent with that of Kumar (2004) and Srivastava (2011), who assumed that the capital market in most of emerging countries is small, and not active globally.

The present study has several limitations. Firstly, the study used the ownership concentration classified by MSM only. Future studies may consider other classifications aside from MSM. Secondly, the current study focused on financial and market performance of firms only. However, non-financial goals can be of equal importance for managers and investors. Therefore, future studies should consider financial and non-financial goals, and assess them in firms with different ownership concentrations.

Different criteria for firm value, such as economic value added and Tobin's Q, can be used in the analysis in future studies, and the results can be subjected to further discussion. Thirdly, the period of study is limited to five years (2011-2015). This time series may be unstable because of its short duration. Future studies may require longer and different time series. Fourthly, the present study was conducted in the MSM, which is considered a small sample in an emerging market. Further studies may be conducted on entire GCC markets, which have several similarities in terms of laws, regulations, and the nature of economies.

\section{CONCLUSION}

The present study investigated the impact of ownership concentration on the performance of all firms listed in three sectors at MSM from 2011 to 2015. The findings are in line with the second stream of literature review, which reveals mixed results. Results show that GCCOC and FOC in the finance and industrial sectors, respectively, have significant and positive impacts on firm performance in terms of ROA. Moreover, a significant and positive impact of OOC and GCCOC on firm performance in terms of MFV is found only in the service sector. This finding indicates that MFV and ROA increase in the case of these ownership structures in a firm because these investors control the unfavourable activities of the top management and make decisions that favour other minor shareholders. The study has a unique finding: none of the types of ownership concentrations have had any impact on ROE in all three of the sectors. The reason behind this result is that investors can maximise their ROA, but not ROE. ROA in Oman is used extensively to evaluate the profitability of companies, because institutional investors prefer its use.

This study has certain implications. Firstly, decision-makers in MSM should encourage companies to disclose further information about other ownership structures, such as family and managerial concentrations. Secondly, the positive and significant relationship between foreign ownership and ROA in the industrial sector appears to have gained universal acceptance. In this respect, MSM has formed a mechanism to monitor this scenario. Thirdly, the results will contribute to the improvement of MSM by improving the corporate governance model in this market. 


\section{REFERENCES}

Abbas, A. H., Naqvi, A. \& Mirza, H. H. (2013). Impact of Large Ownership on Firm Performance: A Case of nonFinancial Listed Companies of Pakistan. World Applied Sciences Journal, 21 (8), 1141-1152, DOI: 10.5829/ idosi.wasj.2013.21.8.1916.

Abdul Rahman, A. N. A., \& Md Reja, B. A. F. (2015). Ownership Structure and Bank Performance. Journal of Economics, Business and Management. 3(5), 483-488.

Ahmad, H. \& Javid, A. (2010). The Ownership Structure and Dividend Payout Policy in Pakistan (Evidence from Karachi stock Exchange 100 Index). International Journal of Business Management and Economic Research, $1(1), 58-69$.

Ahmed, N., \& Hadi, O. A. (2017). Impact of Ownership Structure on Firm Performance in the MENA Region: An Empirical Study. Accounting and Finance Research, 6 (3), 105-115.

Alimehmeti, G., \& Paletta, A. (2012). Ownership Concentration and Effects over Firm Performance: Evidences from Italy. European Scientific Journal, 8(22), 39-49.

Al-Matari, E. M., \& Al arussi, A. S. (2016). The Effect of the Ownership Structure Characteristics on Firm Performance in Oman: Empirical Study. Corporate Ownership and Control Journal, 13(2), 93-100.

Al-Saidi, M., \& Al-Shammari, B. (2014). The Relationship between a Firm's Value and Ownership Structure in Kuwait: Simultaneous Analyses Approach. International Business Research, 7(5), 32-48.

Amran, N. A., \& Ahmed, A. C. (2013). Effects of Ownership Structure on Malaysian Companies Performance. Asian Journal of Accounting and Governance, 4, 51-60.

Chen, L. (2012). The Effect of Ownership Structure on Firm Performance Evidence from Non-financial Listed Companies in Scandinavia. Unpublished master thesis, Aarhus School of Business. Aarhus University. Denmark.

Din, S.D., \& Javid, A. Y. (2011). Impact of Family Ownership concentration on the Firm's Performance: Evidence from Pakistani Capital Market. Online at https://mpra.ub.uni-muenchen.de/37566/ MPRA Paper No. 37566, posted 29. 10:28 UTC.

Fauzi F. and Locke, S. (2012). Board Structure, Ownership Structure and Firm Performance: A case of New Zealand Listed-Firms. Asian Academy of Management Journal of Accounting and Finance, 8 (2), 43-67.

Isik, O., \& Soykan, M. E. (2013). Large Shareholders and Firm Performance: Evidence from Turkey. European Scientific Journal, 9(25), 23-37.

Khamis, R., Hamdan, A. M. \& Elali, W. (2015). The Relationship between Ownership Structure Dimensions and Corporate Performance: Evidence from Bahrain. Australasian Accounting, Business and Finance Journal, 9(4), 38-56.

Khan, F. U., \& Nouman, M. (2017). Does Ownership Structure Affect Firms Performance? Empirical Evidence from Pakistan. Pakistani Business Review, 19 (1),1-23.

Kumar, J. (2004). Does Ownership Structure Influence Firm Value? Evidence from India. The Journal of Entrepreneurial Finance and Business Ventures, 9(2),61 -93.

Kuznetsov, A., Kapelyushnikov, R. \& Dyomina, N. (2010). The Impact of Concentrated Ownership on Firm Performance in an Emerging Markets: Evidence from Russia. https://www.researchgate.net/publication/229051266.

Ministry of Commerce and Industry. (1994). The Foreign Capital Investment. Oman Government Publishing Services.

Ongore, V.O. (2011). The relationship between ownership structure and firm performance: An empirical analysis of listed companies in Kenya. African Journal of Business Management, 5 (6), 2120-2128, DOI: 10.5897/ AJBM10.074.

Owiredu, A., Oppong, M. \& Churchull. R.Q. (2014). Effects of Ownership Structure on the Performance of Listed Companies on the Ghana Stock Exchange. Archives of Business Research, 2(4), 70-86, DOI: 10.14738/ abr.24.346. 
Pathirawasam, C., \& Wickremasinghe, G. (2012). Ownership Concentration and Financial Performance: The Case of Srilankan Listed Companies. Corporate Ownership and Control, 9(4), 170-177.

Qin, Z., Mishra, V. \& Smyth, R. (2012). An Empirical Examination of Endogenous Ownership in Chinese Private Enterprises. Working paper 38-12, Monash University.

Rajput, N., \& Bharti, M. (2015). Shareholder Types, Corporate Governance and Firm Performance: An Anecdote from Indian Corporate Sector. Asian Journal of Finance and Accounting, 7(1), 45-63.

Srithanpong, T. (2012). Foreign Ownership and Firm Performance in the Thai Construction Industry. International Proceedings of Economics Development and Research, 55 (14), 72-76. DOI: 10.7763/IPEDR.

Srivastava, A. (2011). Ownership Structure and Corporate Performance: Evidence from India. International Journal of Humanities and Social Science, 1(1), 23-29.

Unsal, A., Ugurlu, E. \& Sakinc, I. (2009). Ownership Identity and Firm Performance in Manufacturing Companies in Turkey: A Multinational Logit Model Approach. International Journal of Economics and Finance, $1(2), 23-34$.

Vintilă, G., C. Gherghina, Ş. \& Nedelescu, M. (2014). The Effects of Ownership Concentration and Origin on Listed Firms value: Empirical Evidence from Romania. Romanian Journal of Economic Forecasting, XVII (3), 51-71.

Wang, K., \& Shailer, Gr. (2015). Ownership Concentration AND Firm Performance Emerging Markets: A Meta -Analysis. Journal of Economic Surveys, 29 (2), 199-229.

Yasser, Q. R., \& Al Mamun. A. (2017). The Impact of Ownership Concentration on Firm Performance: Evidence from an Emerging Market. Emerging Economy Studies, 3 (1), 34-53, https://doi.org/10.1177/2394901517696647.

Zakaria, Z., Purhanudin, N. \& Palanimally, Y. R. (2014). Ownership Structure and Firm Performance: Evidence from Malaysian Trading and Services Sector. European Journal of Business and Social Sciences, 3 (2), 32-43. 


\section{KONCENTRACIJA VLASNIŠTVA I UČINAK KOMPANIJE: EMPIRIJSKA ANALIZA U OMANU}

\section{Rezime:}

Ovaj radi se bavi uticajem koncentracije vlasništva na učinak firme. Uzorak od 115 kompanija iz Omana, koje su deo tri sektora (odnosno, finansijskog, privrednog i sektora usluga) odabran je za potrebe ovog istraživanja. Navedene kompanije bile su deo tržišta hartija od vrednosti Muskata (Oman) u periodu od pet godina (2011-2015). Analizirane su četiri vrste vlasništva, naime, vlasništvo omanskih investitora, investitora iz zemlje - pripadnica Saveta za zalivsku saradnju, arapski investitori, koji ne pripadaju navedenom Savetu, kao i strani investitori. Učinak firme meren je prinosom na poslovnu imovinu (ROA), prinosom na kapital (ROE), kao i fer tržišnom vrednošću akcija. Panel regresija je upotrebljena kako bi se utvrdili efekti koncentracije vlasništva na učinak firme. Rezultati otkrivaju pozitivan i značajan uticaj, a kada su u pitanju investitori iz zemalja pripadnica Saveta za zalivsku saradnju, odnosno, strani investitori, na prinos na poslovnu imovinu, I to samo u sektoru privrede. Štaviše, pozitivan i značaja uticaj investitora iz Omana i zemalja članica Saveta za zalivsku saradnju na fer tržišnu vrednost, primećen je u sektoru usluga. Naposletku, rezultati nisu ukazali na uticaj koncentracije vlasništva na prinos na kapital - bez obzira na to o kojem je sektoru reč.
Ključne reči:

vlasnička struktura, prinos na poslovnu imovinu, prinos na kapital, fer tržišna vrednost, Oman 